\title{
PENENTUAN KADAR ALKALOID TOTAL EKSTRAK AKAR KUNING (Fibraurea chloroleuca Miers) BERDASARKAN PERBEDAAN KONSENTRASI ETANOL DENGAN METODE SPEKTROFOTOMETRI UV-VIS
}

\section{Determination Of Total Alkaloid Levels Extracts Of Akar Kuning (Fibraurea chloroleuca Miers) Based On The Differences Of Ethanol Concentrations by Spectrofotometry UV-Vis Method}

\author{
Septia Wahyuni, Mauritz Pandapotan Marpaung" \\ Universitas Kader Bangsa, Palembang \\ *email: mauritzchem@gmail.com
}

\begin{abstract}
Abstrak. Akar kuning (Fibraurea chloroleuca Miers) dengan senyawa metabolit sekunder yang terkandung di dalamnya merupakan salah satu tanaman yang berpotensi sebagai tanaman obat tradisional untuk mengobati berbagai penyakit. Tujuan penelitian ini adalah menentukan kadar alkaloid total ekstrak akar kuning dengan perbedaan konsentrasi pelarut etanol yaitu 50\%, 70\%, dan 96\%. Proses ekstraksi menggunakan metode maserasi dan ekstrak diuapkan dengan rotary evaporator pada suhu $40^{\circ} \mathrm{C}$. Identifikasi alkaloid pada ekstrak menggunakan pereaksi Wagner, Mayer dan Dragendorff dan kadar alkaloid total dilakukan dengan metode spektrofotometri UV-Vis. Hasil penelitian menunjukkan identifikasi alkaloid dengan semua pereaksi dinyatakan positif mengandung alkaloid pada ekstrak. Hasil kadar alkaloid total ekstrak akar kuning dengan pelarut etanol $50 \%$ sebesar $0,6939 \pm 0,2439 \%$, dengan pelarut etanol $70 \%$ sebesar 0,6607 $\pm 0,2117 \%$ dan pelarut etanol $96 \%$ sebesar $0,7826 \pm 0,3004 \%$. Berdasarkan hasil penelitian, ekstrak akar kuning dengan konsentrasi pelarut etanol 96\% menunjukkan kadar alkaloid yang tertinggi.
\end{abstract}

Kata kunci: Akar kuning, alkaloid, etanol

\begin{abstract}
Akar kuning (Fibraurea chloroleuca Miers) with its secondary metabolite compounds is one of the plants that has the potential as a traditional medicinal plant to treat various diseases. This study aimed to determine the total alkaloid content of akar kuning extract with differences in the concentration of ethanol solvent namely 50\%, 70\%, and $96 \%$. The extraction process used the maceration method and extracts were evaporated by a rotary evaporator at a temperature of $40^{\circ} \mathrm{C}$. The identification of alkaloids in the extract used Wagner, Mayer, and Dragendorff reagents and the total alkaloid levels were carried out by the UV-Vis spectrophotometric method. The results showed that the identification of alkaloids with all reagents were tested positive for containing alkaloids in the extract. The results of the total alkaloid level of akar kuning extracts with ethanol $50 \%$ was $0.6939 \pm 0.2439 \%$, ethanol $70 \%$ was $0.6607 \pm 0.2117 \%$, and ethanol $96 \%$ was $\pm 0.7826 \pm 0.3004 \%$,. Based on the results, akar kuning extract with a solvent concentration of ethanol $96 \%$ showed the highest alkaloid levels.
\end{abstract}

Keywords: Akar kuning, alkaloid, ethanol 


\section{PENDAHULUAN}

Akar kuning merupakan salah satu tumbuhan liar yang terdapat di daerah hutan atau pinggiran sungai yang batangnya dapat merambat mencapai $20 \mathrm{~m}$ pada tumbuhan lain. Tumbuhan yang berada di ketinggian $800 \mathrm{~m}$ dpl (di atas permukaan laut) ini memiliki batang yang berwarna kuning dengan daun yang lebarnya 7-20 cm, berbentuk lonjong, mengkilap dan lebat. (Subiandono \& Heriyanto, 2009). Tumbuhan ini tumbuh tersebar di beberapa pulau di Indonesia seperti pulau Sumatera dan pulau Kalimanta (Suratno dkk, 2019).

Akar kuning telah dimanfaatkan sebagai obat tradisional oleh mayarakat Dayak di Kalimantan untuk mengobati berbagai penyakit khususnya gangguan pada hati seperti hepatitis, sirosis hepatis, hepatomegali, dan penyakit kuning. Selain itu, akar kuning juga memiliki berbagai khasiat dalam pengobatan seperti menetralkan racun dari ular berbisa, mengobati penyakit kencing manis, dapat menghambat pertumbuhan dan mematikan sel kanker, meningkatkan pertumbuhan sel hati, sebagai antiinflamasi dan dapat meningkatkan daya tahan tubuh. Adanya berbagai khasiat yang dimiliki oleh akar kuning disebabkan adanya peranan senyawa aktif yang terkandung di dalamnya. Kandungan senyawa aktif yang terdapat dalam akar kuning pada bagian akar berupa steroid, alkaloid, tanin, saponin, dan fenolhidrokuinon. Pada bagian batang, akar kuning mengandung senyawa palmatine, berberine, jatrorrhizine, dihydroberberine, dan 20hydroxyecdysone (Balitbang Palangkaraya, 2018).

Untuk menjadikan akar kuning sebagai bahan baku obat tradisional yang sesuai standar dan aman dikonsumsi perlu dilakukan uji farmakologi dan penapisan fitokimia. Secara farmakologi, akar kuning mempunyai aktivitas diuretik yang diuji dengan tikus putih jantan galur Wistar dan aktivitas sebagai antiradikal bebas yang sangat kuat (Marpaung dkk, 2017; Marpaung \& Handayani, 2018). Pada penapisan fitokimia secara kualitatif, akar kuning mengandung senyawa metabolit sekunder berupa flavonoid, alkaloid, saponin, tanin, dan triterpenoid (Marpaung dkk, 2017). Secara kuantitatif, akar kuning mengandung flavonoid dengan kadar total sebesar 0,31031 $\pm 0,013607 \%$ (Marpaung \& Wahyuni, 2018). Selain itu, akar kuning juga mengandung jenis saponin triterpenoid dengan kadar sebesar 4,51 $\pm 0,2805 \%$ (Wira \& Marpaung, 2020). Untuk penetapan kadar alkaloid total pada akar kuning belum ditentukan hingga saat ini.

Alkaloid merupakan salah satu jenis senyawa metabolit sekunder yang terdapat dalam jaringan tumbuhan dan hewan yang bersifat alkali yang mengandung atom nitrogen (N) dengan struktur lingkar yang heterosiklik atau aromatis (Hanani, 2015). Peranan alkaloid secara farmakologis dapat mengobati diare, diabetes, malaria, dan antimikroba (Fattorusso \& Taglialatela-Scafati, 2007). Dalam menentukan kadar alkaloid dapat dilakukan dengan beberapa metode seperti gravimetri, spektrodensitometri, dan spektrofotometri visibel (Alasa dkk, 2017; Mukhaimin dkk, 2015; Salamah dkk, 2017).

Untuk memaksimalkan penyarian kandungan alkaloid pada ekstrak akar kuning diperlukan pelarut dengan konsentrasi yang tepat. Secara umum pelarut yang sering digunakan dalam ekstraksi adalah etanol dengan banyak keunggulan seperti tidak toksik, mempunyai daya absorbsi yang baik, bersifat selektif dan dapat menyari berbagai senyawa aktif. Dengan adanya perbedaan atau variasi konsentrasi pelarut etanol akan mempengaruhi nilai rendemen, aktivitas, dan kandungan suatu ekstrak. Penelitian ini menggunakan pelarut etanol dengan konsentrasi 50\%, 70\%, dan $96 \%$ untuk 
mennentukan kadar alkaloid total yang tersari dalam ekstrak akar kuning dengan metode spektrofotometri UV-Vis. Dengan adanya variasi konsentrasi pelarut etanol diharapkan dapat menentukan konsentrasi pelarut yang tepat dalam menyari senyawa aktif yang tergolong alkaloid di dalam ekstrak akar kuning.

\section{METODE PENELITIAN \\ Alat dan Bahan}

Alat-alat yang digunakan dalam penelitian ini adalah timbangan analitik seperangkat alat maserasi, rotary evaporator, gelas ukur, gelas kimia, labu ukur, kertas saring, cawan porselen, tabung reaksi, rak tabung reaksi, pipet tetes, mikro pipet tetes, dan spektrofotometer UV-Vis.

Bahan-bahan kimia yang digunakan adalah etanol p.a (Merck), akuades, $\mathrm{HCl}$, pereaksi Dragendorff, pereaksi Mayer, pereaksi Wagner, $\mathrm{NaOH}, \mathrm{Na}_{2} \mathrm{HPO}_{4}$, asam sitrat, Bromocresol Green (BCG), Dapar posfat ( $\mathrm{pH} 4,7$ ), kafein, kloroform, dan aerosol.

Bahan uji yang digunakan adalah akar kuning yang diperoleh dari Desa Sengir, Kecamatan Payung, Kabupaten Bangka Selatan, Provinsi Kepulauan Bangka Belitung dan dideterminasi di Laboratorium Herbarium, FMIPA Biologi Universitas Andalas, Padang.

\section{Ekstraksi Akar Kuning}

Akar kuning disortasi basah dan kering untuk memperoleh simplisia setelah dilakukan penghalusan dan penyaringan dengan ayakan mesh no. 40. Masing-masing sebanyak $50 \mathrm{~g}$ simplisia diekstrak dengan metode maserasi menggunakan pelarut etanol 50\%, 70\% dan 96\% selama 3 hari dengan dua kali pengulangan. Kemudian disari dan diuapkan dengan rotary evaporator pada suhu $40^{\circ} \mathrm{C}$ dan dihitung rendemen masingmasing konsentrasi ekstrak etanol (Marpaung \& Romelan, 2018).

\section{Identifikasi Alkaloid}

Sebanyak 0,5 g serbuk simplisia ditambahkan $1 \mathrm{~mL} \mathrm{HCl} 2 \mathrm{~N}$ dan $9 \mathrm{~mL}$ air suling. Lalu dipanaskan di atas penangas air selama 2 menit, didinginkan dan disaring. Filtrat diambil 3 tetes, lalu ditambahkan 2 tetes pereaksi Mayer akan menghasilkan endapan putih atau kuning. Kemudian filtrat diambil 3 tetes, lalu ditambahkan 2 tetes pereaksi Wagner menghasilkan endapan coklat-hitam. Selanjutnya filtrat diambil 3 tetes, lalu ditambahkan 2 tetes pereaksi Dragendorff menghasilkan endapan merah bata. Alkaloid dianggap positif apabila terbentuk endapan paling sedikit dua atau tiga dari percobaan di atas (Nurhayat dkk, 2020).

\section{Pembuatan larutan baku kafein}

$250 \mathrm{mg}$ kafein dilarutkan dengan akuades panas dan dimasukkan ke dalam labu ukur $250 \mathrm{ml}$ sehingga ehingga diperoleh konsentrasi $1000 \mathrm{ppm}$. Kemudian dipipet sebanyak 2,5 mL dan ditambahkan akuades ke dalam labu ukur $25 \mathrm{~mL}$ sehingga diperoleh konsentrasi 100 ppm (Arwangga dkk, 2016).

\section{Penentuan Panjang Gelombang Maksimum $\left(\lambda_{\text {maks }}\right)$ Kafein}

Penentuan panjang gelombang maksimum larutan kafein menggunakan spektrofotometer UV Vis pada panjang gelombang 200-400 nm. Hasil panjang 
gelombang maksimum standar baku kafein berada pada $273 \mathrm{~nm}$. Panjang gelombang maksimum tersebut digunakan untuk mengukur serapan dari sampel ekstrak etanol akar kuning.

\section{Pembuatan Kurva Standar Kafein}

Mengambil 0,$1 ; 0,3 ; 0,6 ; 0,9 ; 1,2 ;$ dan $1,5 \mathrm{~mL}$ dari larutan standar kafein 100 ppm dan diencerkan sampai $10 \mathrm{~mL}$ sehingga diperoleh konsentrasi larutan standar berturut-turut adalah $1 ; 3 ; 6 ; 9 ; 12$; dan 15 ppm. Kemudian diukur absorbansi pada panjang gelombang $273 \mathrm{~nm}$ dengan menggunakan spektrofotometer UV Vis (Arwangga dkk, 2016).

\section{Pembuatan Larutan Induk Ekstrak Akar Kuning 100 ppm}

Ditimbang $10 \mathrm{mg}$ ekstrak akar kuning dan dilarutkan sampai $10 \mathrm{~mL}$ masingmasing konsentrasi etanol, kemudian dikocok hingga homogen sehingga diperoleh konsentrasi $1000 \mathrm{ppm}$. Lalu dipipet sebanyak $1 \mathrm{~mL}$ dan ditambah masing-masing etanol sampai dengan $10 \mathrm{~mL}$. lalu dikocok sampai homogen sehingga diperoleh konsentrasi $100 \mathrm{ppm}$.

\section{Pembuatan Larutan Ekstrak Akar Kuning}

Dipipet 0,$1 ; 0,3 ; 0,6 ; 0,9 ; 1,2$ dan $1,5 \mathrm{~mL}$ larutan induk ekstrak masing-masing ke labu ukur ukuran $10 \mathrm{~mL}$. Lalu ditambahkan dengan etanol konsentrasi masing-masing hingga tanda batas untuk membuat masing-masing konsentrasi ekstrak $1 ; 3 ; 6 ; 9 ; 12$; dan $15 \mathrm{ppm}$.

\section{Penentuan Kadar Alkaloid Total Ekstrak Akar Kuning}

Mengambil $2 \mathrm{~mL}$ ekstrak akar kuning masing-masing konsentrasi ekstrak. Lalu ditambahkan dapar posfat dan larutan BCG. Kemudian diekstraksi dengan kloroform sebanyak tiga kali menggunakan vortex. Diambil fase kloroform dan dimasukkan ke dalam labu ukur $10 \mathrm{~mL}$ dan ditambahkan kloroform sampai batas volume. Lalku diukur absorbansi pada panjang gelombang $273 \mathrm{~nm}$.

\section{Analisa data}

Penentuan kadar alkaloid total dilakukan dengan mencari nilai regresi dan perhitungan koefesien variasi regresi linier. Setelah itu dilakukan perhitungan kadar alkaloid total ekstrak etanol akar kuning dengan menggunakan rumus $\mathrm{y}=\mathrm{bx}+\mathrm{a}$. Dari rumus tersebut maka akan diperoleh kadar alkaloid total dan nilai Standar Deviasi (SD).

\section{HASIL PENELITIAN DAN PEMBAHASAN}

Dalam pembuatan ekstrak dilakukan proses pencucian bahan untuk menghilangkan kotoran yang terdapat pada bahan. Kemudian dilakukan pengeringan di bawah matahari secara tidak langsung untuk mengurangi kandungan air dan mencegah pertumbuhan mikroba di dalam bahan. Lalu dihaluskan dan diayak untuk memperoleh serbuk simplisia dengan ukuran yang homogen. Hal ini bertujuan untuk mempermudah pelarut menarik senyawa aktif pada bahan. Semakin kecil ukuran partikel dari suatu bahan maka semakin besar luas permukaan bahan sehingga pelarut akan semakin mudah melarutkan senyawa aktif dari suatu bahan. 
Metode ekstraksi yang digunakan adalah maserasi dengan merendam dan menggojok simplisia beberapa kali di dalam pelarut organik pada suhu ruangan. Metode ini memiliki beberapa kelebihan diantaranya alat dan proses yang digunakan sederhana, bahan yang diekstraksi tidak mengalami kerusakan pada senyawa aktif akibat pemanasan, biaya pelaksanaan relatif tidak tinggi, dan dapat mengekstraksi bahan alam yang tidak tahan pada suhu yang tinggi.

Untuk menentukan hasil ekstraksi, dilakukan perhitungan rendemen yang merupakan perbandingan bobot ekstrak yang diperoleh terhadap bobot simplisia yang diekstraksi. Rendemen memberikan gambaran mengenai kandungan senyawa aktif yang tersari dalam suatu bahan. Semakin besar nilai suatu rendemen maka semakin banyak senyawa aktif yang tersari dalam suatu bahan. Hasil ekstraksi memberikan nilai rendemen pada ekstrak etanol 50\% sebesar 22,74\%, ekstrak etanol 70\% sebesar 14,52\%, dan ekstrak etanol $96 \%$ sebesar 3,80\% (Tabel 1). Nilai rendemen tertinggi terdapat pada ekstrak etanol 50\%. Hal ini menunjukkan bahwa pelarut etanol 50\% dapat menyari lebih banyak jenis senyawa aktif yang terkandung dalam ekstrak akar kuning. Etanol dengan konsentrasi 50\% merupakan campuran dengan 50 bagian etanol dan 50 bagian air. Air yang merupakan pelarut bersifat polar akan menarik seluruh senyawa aktif yang bersifat polar sedangkan etanol yang memiliki tingkat kepolaran lebih rendah dari air dapat menarik senyawa aktif dengan berbagai tingkat kepolaran yang berbeda yaitu polar, semipolar, dan nonpolar seperti flavonoid, tanin, antrakuinon, terpenoid, saponin, dan alkaloid ((Harbone, 1996). Adanya kemampuan pelarut dapat menyari senyawa aktif dalam ekstrak didasarkan pada prinsip like dissolves like yaitu suatu senyawa dapat tersari dalam pelarut ketika memiliki sifat kepolaran yang sama.

Tabel 1. Rendemen ekstrak etanol akar kuning

\begin{tabular}{lccc}
\hline Nama ekstrak & Bobot simplisia & Bobot ekstrak & Rendemen \\
\hline Ekstrak etanol 50\% & $50 \mathrm{~g}$ & $11,37 \mathrm{~g}$ & $22,74 \%$ \\
Ekstrak etanol 70\% & $50 \mathrm{~g}$ & $7,26 \mathrm{~g}$ & $14,52 \%$ \\
Ekstrak etanol $96 \%$ & $50 \mathrm{~g}$ & $1,9 \mathrm{~g}$ & $3,80 \%$ \\
\hline
\end{tabular}

Untuk mengetahui adanya kandungan alkaloid dalam ekstrak dilakukan secara kualitatif dengan pereaksi Wagner, Mayer, dan Dragendorff. Pada Tabel 2 menunjukkan hasil uji kualitatif untuk tiga pereaksi tersebut mengandung alkaloid pada ekstrak akar kuning. Penambahan $\mathrm{HCl}$ pekat dalam uji kualitatif alkaloid pada ekstrak bertujuan untuk meningkatkan daya larut alkaloid yang bersifat basa membentuk suatu garam. Prinsip uji kualitatif ini didasarkan pada reaksi presipitasi akibat dari pergantian ligan antara atom nitrogen dengan sepasang elektron bebas pada alkaloid terhadap ion iodo pada pereaksi-pereaksi tersebut (Ergina dkk, 2014).

Tabel 2. Hasil uji kualitatif alkaloid ekstrak akar kuning

\begin{tabular}{cccc}
\hline Pereaksi & Kriteria uji & Hasil uji & Kesimpulan \\
\hline Wagner & Endapan coklat & Endapan coklat & $(+)$ \\
Mayer & Endapan putih/kuning & Endapan kuning & $(+)$ \\
Dragendorff & Endapan jingga kecoklatan & Endapan jingga kecoklatan & $(+)$ \\
\hline
\end{tabular}

Keterangan:

(+) : mengandung alkaloid 
Pereaksi Wagner merupakan larutan yang berasal dari pencampuran iodin $\left(\mathrm{I}_{2}\right)$ dengan kalium iodida (KI) yang dilarutkan dalam akuades. Hasil yang diperoleh dari uji alkaloid dari pereaksi tersebut adalah adanya endapan coklat yang berasal pembentukan ion $\mathrm{I}_{3}{ }^{-}$dari reaksi iodin $\left(\mathrm{I}_{2}\right)$ dengan ion $\mathrm{I}^{-}$yang berasal dari KI. Hal ini disebabkan adanya ikatan antara atom nitrogen $(\mathrm{N})$ yang memiliki pasangan elektron bebas pada alkaloid terhadap ion logam $\mathrm{K}^{+}$membentuk senyawa kompleks kalium-alkaloid melalui ikatan kovalen koordinasi (Ikalinus dkk, 2015).

Pada pereaksi Mayer akan menghasilkan endapan putih/kuning dalam uji alkaloid pada ekstrak. Pereaksi Mayer merupakan campuran larutan raksa(II) klorida $\left(\mathrm{HgCl}_{2}\right)$ dengan larutan kalium iodida (KI) membentuk raksa(II) iodida $\left(\mathrm{HgI}_{2}\right)$. Apabila dilakukan penambahan larutan KI yang berlebih akan membentuk endapan senyawa kompleks kalium tetraiodomerkurat(II), $\mathrm{K}_{2}\left[\mathrm{HgI}_{4}\right]$. Pada uji Mayer, atom nitrogen dengan sepasang elektron bebas pada alkaloid bereaksi dengan kalium tetraiodomerkurat(II) membentuk endapan kompleks kalium-alkaloid (Wardhani \& Supartono, 2015).

Pada uji alkaloid dengan pereaksi Dragendorff menghasilkan endapan jingga kecoklatan. Hal ini disebabkan adanya reaksi atom nitrogen pada alkaloid terhadap ion logam $\mathrm{K}^{+}$pada senyawa kompleks kalium tetraiodobismutat(III) membentuk kompleks kalium-alkaloid dengan ikatan kovalen koordinasi dan ion kompleks tetraiodobismutat(III), $\left[\mathrm{BiI}_{4}\right]^{-}$. Pereaksi Dragendorff adalah campuran larutan bismut nitrat dalam asam klorida untuk mencegah terjadinya reaksi hidrolisis dengan larutan kalium iodida menghasilkan endapan hitam bismut(III) iodida $\left(\mathrm{BiI}_{3}\right)$. Apabila dilakukan penambahan berlebih larutan kalium iodida, endapan tersebut akan melarut kembali menghasilkan larutan kompleks kalium tetraiodobismutat(III), K[BiI $\left.{ }_{4}\right]$ (Ergina dkk, 2014).

Secara kuantitatif, pengukuran kadar alkaloid ekstrak akar kuning menggunakan spektrofotometer UV-Vis. Spektrofotometer UV-Vis merupakan salah satu instrumen yang digunakan secara kuantitatif untuk menentukan kandungan senyawa dalam suatu sampel yang diukur pada daerah ultraviolet-sinar tampak dengan panjang gelombang 200-700 nm. Hasil pengukuran dari instrumen ini berupa serapan (absorbansi) berdasarkan hukum Lambert-Beer dari beberapa konsentrasi larutan standar atau sampel. Absorbansi tersebut dianalisis untuk memperoleh suatu kurva baku. Kurva baku memberikan gambaran nilai koefisien korelasi $(r)$ dan persamaan regresi linear yaitu $\mathrm{y}=$ $\mathrm{ax}+\mathrm{b}$. Persaman tersebut digunakan untuk menentukan kandungan senyawa dari suatu sampel yang dianalisis.

Tabel 3. Absorbansi standar kafein

\begin{tabular}{cc}
\hline Konsentrasi (ppm) & Absorbansi \\
\hline 1 & 0,055 \\
3 & 0,118 \\
6 & 0,275 \\
9 & 0,401 \\
12 & 0,533 \\
15 & 0,635 \\
\hline
\end{tabular}

Larutan baku (standar) yang digunakan adalah kafein untuk menentukan panjang gelombang maksimum senyawa alkaloid dan penetapan kurva baku. Panjang gelombang 
Dalton : Jurnal Pendidikan Kimia dan Ilmu Kimia, Volume 3 Nomor 2, November 2020

maksimum yang dihasilkan yaitu $273 \mathrm{~nm}$. Pada hasil pengukuran serapan menunjukkan hubungan antara konsentrasi kafein dengan absorbansi yang dihasilkan berbanding lurus. Semakin besar konsentrasi kafein, absorbansi yang dihasilkan semakin besar (Tabel 2). Kafein dengan rumus molekul $\mathrm{C}_{8} \mathrm{H}_{10} \mathrm{~N}_{4} \mathrm{O}_{2}$ merupakan senyawa alkaloid golongan xantin dengan struktur inti purin yang berbentuk kristal, larut dalam air, memiliki aroma yang wangi dan rasa yang pahit. Senyawa ini secara alami terdapat di dalam biji kopi yang memiliki beberapa peranan secara farmakologis diantaranya sebagai perangsang sehingga dapat mencegah rasa kantuk, dapat meningkatkan daya tangkap pancaindera, dan mempercepat kemampuan berpikir (Arwangga dkk, 2016)

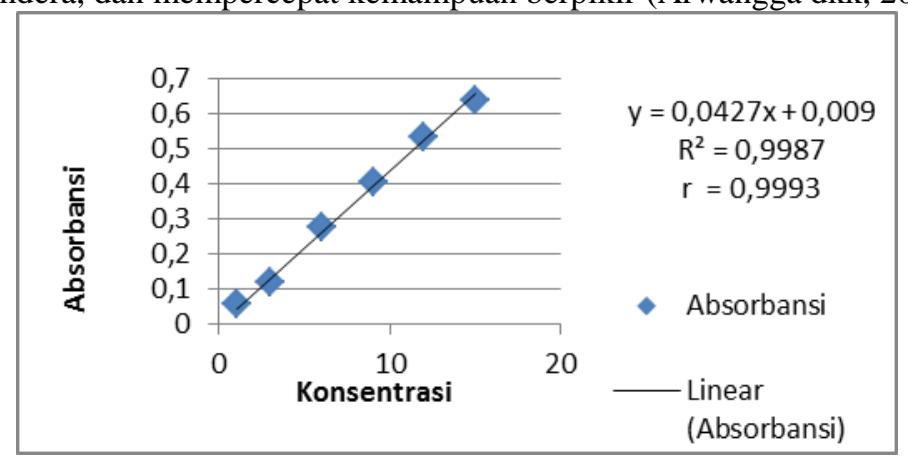

Gambar 1. Kurva baku larutan kafein

Tabel 4. Kadar alkaloid total ekstrak etanol 50\% akar kuning

\begin{tabular}{ccccc}
\hline Konsentrasi & Absorbansi & $\begin{array}{c}\text { Konsentrasi } \\
\text { ekstrak }\end{array}$ & $\begin{array}{c}\text { Kadar alkaloid } \\
\text { awal }(\mathrm{ppm})\end{array}$ & $\begin{array}{c}\text { Kadar alkaloid total } \\
(\%)\end{array}$ \\
\hline $1 \mathrm{ppm}$ & 0,414 & & 9,484 & 0,9484 \\
$3 \mathrm{ppm}$ & 0,222 & & 4,988 & 0,4988 \\
$6 \mathrm{ppm}$ & 0,142 & & 3,114 & 0,3114 \\
$9 \mathrm{ppm}$ & 0,321 & $1000 \mathrm{ppm}$ & 7,306 & 0,7306 \\
$12 \mathrm{ppm}$ & 0,343 & & 7,822 & 0,7822 \\
$15 \mathrm{ppm}$ & 0,390 & & 8,922 & 0,8922 \\
Rata-rata kadar alkaloid total & & & 0,6939 \\
Standar deviasi & & & 0,2439 \\
\hline
\end{tabular}

Tabel 5. Kadar alkaloid total ekstrak etanol $70 \%$ akar kuning

\begin{tabular}{ccccc}
\hline Konsentrasi & Absorbansi & $\begin{array}{c}\text { Konsentrasi } \\
\text { ekstrak }\end{array}$ & $\begin{array}{c}\text { Kadar alkaloid } \\
\text { awal }(\mathrm{ppm})\end{array}$ & $\begin{array}{c}\text { Kadar alkaloid total } \\
(\%)\end{array}$ \\
\hline $1 \mathrm{ppm}$ & 0,224 & & 5,035 & 0,5035 \\
$3 \mathrm{ppm}$ & 0,366 & & 8,360 & 0,8360 \\
$6 \mathrm{ppm}$ & 0,186 & & 4,145 & 0,4145 \\
$9 \mathrm{ppm}$ & 0,406 & $1000 \mathrm{ppm}$ & 9,297 & 0,9297 \\
$12 \mathrm{ppm}$ & 0,226 & & 5,081 & 0,5081 \\
$15 \mathrm{ppm}$ & 0,339 & 7,728 & 0,7728 \\
Rata-rata kadar alkaloid total & & 0,6607 \\
Standar deviasi (SD) & & 0,2117 \\
\hline
\end{tabular}


Tabel 6. Kadar alkaloid total ekstrak etanol $96 \%$ akar kuning

\begin{tabular}{ccccc}
\hline Konsentrasi & Absorbansi & $\begin{array}{c}\text { Konsentrasi } \\
\text { ekstrak }\end{array}$ & $\begin{array}{c}\text { Kadar alkaloid } \\
\text { awal }(\mathrm{ppm})\end{array}$ & $\begin{array}{c}\text { Kadar alkaloid total } \\
(\%)\end{array}$ \\
\hline $1 \mathrm{ppm}$ & 0,256 & & 5,579 & 0,5579 \\
$3 \mathrm{ppm}$ & 0,220 & & 4,941 & 0,4941 \\
$6 \mathrm{ppm}$ & 0,226 & & 5,081 & 0,5081 \\
$9 \mathrm{ppm}$ & 0,493 & $1000 \mathrm{ppm}$ & 11,334 & 1,1334 \\
$12 \mathrm{ppm}$ & 0,39 & & 8,922 & 0,8922 \\
$15 \mathrm{ppm}$ & 0,483 & 11,100 & 1,11 \\
Rata-rata kadar alkaloid total & & & 0,7826 \\
\multicolumn{2}{l}{ Standar deviasi } & & & 0,3004 \\
\hline
\end{tabular}

Dari kurva baku diperoleh persamaan regresi linear yaitu $y=0,0427 x+0,009$ dimana y adalah serapan dan $\mathrm{x}$ sebagai konsentrasi sampel dengan nilai kuadrat koefisen korelasi $\left(R^{2}\right)$ sebesar 0,9987 . Nilai $\mathbf{R}^{2}$ memberikan nilai koefisien korelasi (r) sebesar 0,9993 yang menunjukkan hubungan antara konsentrasi ekstrak dengan absorbansi sangat kuat (Gambar 1). Nilai (r) yang mendekati 1 memiliki hubungan yang sangat kuat antar dua variabel dengan membentuk kurva yang linear (Winahyu dkk, 2019).

Kadar alkaloid total tertinggi ekstrak akar kuning terdapat pada ekstrak etanol $96 \%$ sebesar 0,7826 $\pm 0,3004 \%$ (Tabel 3). Hal ini menunjukkan bahwa kandungan alkaloid pada ekstrak akar kuning paling baik tersari dengan menggunakan etanol $96 \%$. Etanol 96\% memiliki komposisi campuran etanol yang lebih banyak dari air dengan perbandingan 24:1. Hal ini memperlihatkan bahwa etanol dengan sifat yang dapat mengikat berbagai senyawa aktif dengan tingkat kepolaran yang berbeda beda dapat menyari lebih banyak senyawa-senyawa alkaloid dan turunannya yang juga memiliki berbagai tingkat kepolaran dibandingkan dengan air yang hanya memiliki sifat polar. Alkaloid dalam tumbuhan secara umum berbentuk garam, yaitu berkaitan dengan asamasam organik yang terdapat dalam tumbuhan, seperti asam suksinat, maleat, mekonat, kinat dan bersifat larut dalam pelarut polar etanol maupun air (Bribi, 2018).

Dengan adanya kandungan alkaloid dalam ekstrak akar kuning, maka akar kuning memiliki potensi sebagai obat alam tradisional. Hal ini dilatarbelakangi alkaloid memiliki peranan penting bagi tumbuhan yang terkandung di dalamnya dan manusia dalam pengobatan. Pada tumbuhan, alkaloid dengan sifat basanya berperan untuk mempertahankan keseimbangan ion dengan menggantikan basa mineral dalam tumbuhan. Alkaloid juga berfungsi sebagai pengatur pertumbuhan, cadangan makanan yang dapat menyalurkan nitrogen dan unsur-unsur lain yang diperlukan oleh tumbuhan. dan pertahanan diri dari serangan mikroorganisme, herbivora, dan serangga. Secara farmakologi, alkaloid dengan senyawa Lycorine dapat berperan sebagai anti-leukemia, anti-tumor, antivirus, dan antimalaria. Senyawa Homolycorine yang merupakan salah satu senyawa beracun alkaloid dapat menghambat pertumbuhan sel tumor secara in vivo dan in vitro. Senyawa tazettine pada alkaloid dapat menghambat pembentukan protein pada virus dan berberine dapat digunakan sebagai antibiotik dan meningkatkan aktivitas pada jaringan adiposa (Ningrum dkk, 2016).

Berdasarkan struktur utama yang dimiliki alkaloid yaitu ikatan utama C-N dibagi menjadi 3 (tiga) jenis yaitu alkaloid sejati, pseudoalkaloid, dan protoalkaloid. Alkaloid sejati merupakan hasil sintesis dari asam amino dengan kandungan atom $\mathrm{N}$ dalam sistem heterosiklik. Di dalam tumbuhan, jenis alkaloid ini ditemukan dalam bentuk garam, 
bebas, atau oksida-N. Senyawa yang termasuk jenis ini adalah kokain, kuinin, morfin, dan nikotin. Pseudoalkaloid adalah jenis kelompok senyawa yang memiliki atom $\mathrm{N}$ dalam kerangka karbon yang tidak berasal dari asam amino dengan prekursor seperti asam asetat, geraniol, asam ferulat, adenin/guanin. Senyawa yang termasuk jenis ini adalah xantin (kafein, teofilin, teobromin), solasodin, dan kapsaisin, Protoalkaloid merupakan alkaloid minor yang memiliki struktur sederhana dengan atom $\mathrm{N}$ yang tidak berasal dari dalam sistem heterosiklik asam amino. Senyawa yang merupakan jenis protoalkaloid adalah efedrin, meskalin, dan hordenin (Hanani, 2015).

\section{SIMPULAN}

Ekstrak akar kuning mengandung senyawa metabolit sekunder alkaloid dengan kadar dalam pelarut etanol $50 \%$ sebesar $0,6939 \pm 0,2439 \%$, dalam pelarut etanol $70 \%$ sebesar $0,6607 \pm 0,2117 \%$, dan dalam pelarut etanol $96 \%$ sebesar $0,7826 \pm 0,3004 \%$. Kandungan alkaloid total tertinggi dalam ekstrak terdapat pada pelarut etanol $96 \%$.

\section{DAFTAR RUJUKAN}

Alasa, A. N., Anam, S., \& Jamaluddin, J. (2017). Analisis Kadar Total Metabolit Sekunder Ekstrak Etanol Daun Tamoenju (Hibiscus surattensis L.). Kovalen, 3(3), 258-268.

Arwangga, A. F., Raka Astiti Asih, I. A., \& Sudiarta, I. W. (2016). Analisis Kandungan Kafein Pada Kopi Di Desa Sesaot Narmada Menggunakan Spektrofotometri UVVis. Jurnal Kimia, 10(1), 110-114.

Balitbang Palangkaraya. (2018). Khasiat Akar Kuning Kalimantan Untuk Kesehatan. https://balitbangkota.palangkaraya.go.id/khasiat-akar-kuning-kalimantan-untukkesehatan/

Bribi, N. (2018). Pharmacological activity of Alkaloids: A Review. Asian Journal of Botany, 1(1), 1-6.

Ergina, Nuryanti, S., \& Pursitasari, I. D. (2014). Uji Kualitatif Senyawa Metabolit Sekunder pada Daun Palado (Agave angustifolia) yang Diekstraksi dengan Pelarut Air dan Etanol. Jurnal Akademika Kimia, 3(3), 165-172.

Fattorusso, E., \& Taglialatela-Scafati, O. (2007). Modern Alkaloids: Structure, Isolation, Synthesis and Biology. In Modern Alkaloids: Structure, Isolation, Synthesis and Biology. Wiley-VCH.

Hanani, E. (2015). Analisis Fitokimia. Penerbit Buku Kedokteran EGC.

Harbone, J. B. (1996). Metode Fitokimia: Penuntun cara modern menganalisis tumbuhan. ITB.

Ikalinus, R., Widyastuti, S., \& Eka Setiasih, N. (2015). Skrining fitokimia ekstrak etanol kulit batang kelor (Moringa oleifera). Indonesia Medicus Veterinus, 4(1), 71-79.

Marpaung, M. P., \& Handayani, D. W. (2018). The effect of solvent concentration on antioxidant activity of akar kuning (Fibraurea chloroleuca Miers) extract. AIP Conference Proceedings, 2049(December), 030003-1-030003-5.

Marpaung, M. P., Mardiansah, Y., \& Wulandari, W. (2017). Aktivitas Diuretik Dan Skrining Fitokimia Ekstrak Etanol Akar Kuning (Fibraurea chloroleuca Miers) Pada Tikus Putih Jantan Galur Wistar. Prosiding Seminar Nasional POKJANAS TOI Ke 52, April, 277-285. 
Marpaung, M. P., \& Romelan, R. (2018). Analisis Jenis dan Kadar Saponin Ekstrak Metanol Daun Kemangi (Ocimum basilicum L.) dengan Menggunakan Metode Gravimetri. JFL : Jurnal Farmasi Lampung, 7(2), 81-86.

Marpaung, M. P., \& Wahyuni, R. C. (2018). Identifikasi Dan Penetapan Kadar Flavonoid Total Ekstrak Akar Kuning (Fibraurea chloroleuca Miers). Talenta Conference Series: Tropical Medicine (TM), 95-98.

Mukhaimin, I., Latifahnya, A. N., \& Puspitasari, E. (2015). Isolasi Dan Penetapan Kadar Alkaloid Ekstrak Etanolik Bunga Kembang Sepatu (Hibiscus rosa-sinensis L.) Secara Spektrodensitometri. Traditional Medicine Journal, 20(2), 112-118.

Ningrum, R., Purwanti, E., \& Sukarsono. (2016). Identifikasi Senyawa Alkaloid dari Batang Karamunting (Rhodomyrtus tomentosa) Sebagai Bahan Ajar Biologi Untuk SMA Kelas X. Jurnal Pendidikan Biologi Indinesia, 2(3), 231-236.

Nurhayat, Yuliar, \& Marpaung, M. P. (2020). Analisis Efek Konsentrasi Ekstrak Etanol Daun Senggani (Melastoma malabathricumL.) Sebagai Antibakteri Staphylococcus aureus. Jurnal Kesehatan Poltekkes Kemenkes RI Pangkalpinang, $8(1), 17-26$.

Salamah, N., Rozak, M., \& Al Abror, M. (2017). Pengaruh Metode Penyarian Terhadap Kadar Alkaloid Total Daun Jembirit (Tabernaemontana sphaerocarpa. BL) dengan Metode Spektrofotometri Visibel. Pharmaciana, 7(1), 113-122.

Subiandono, E., \& Heriyanto, N. (2009). Kajian Tumbuhan Obat Akar Kuning (Arcangelisia flava Merr.). Pusat Penelitian Dan Pengembangan Hutan Dan Konservasi Alam, 15(1), 43-48.

Suratno, S., Rizki, M. I., \& Pratama, M. R. F. (2019). In-Vitro Study of Antioxidant Activities from Ethanol Extracts of Akar Kuning (Arcangelisia flava). Jurnal Surya Medika, 4(2), 66-71.

Wardhani, R. A. P., \& Supartono, S. (2015). Uji Aktivitas Antibakteri Ekstrak Kulit Buah Rambutan (Nephelium lappaceum L.,) Pada Bakteri. IJCS - Indonesia Journal of Chemical Science, 4(1), 46-51.

Winahyu, D. A., Retnaningsih, A., \& Aprilia, M. (2019). Penetapan Kadar Flavonoid Pada Kulit Batang Kayu Baru Dengan Metode Spektrofotometri UV-Vis. Jurnal Analisis Farmasi, 4(1), 29-36.

Wira, D., \& Marpaung, M. P. (2020). Analisis jenis dan kadar saponin ekstrak akar kuning secara gravimetri. Dalton: Jurnal Pendidikan Kimia dan Ilmu Kimia, 3(1), $51-59$. 